\title{
Engagement of the periesophageal ring during Holothuria polii response to erythrocyte injection
}

\author{
G. D’Ancona Lunetta ${ }^{1}$ and M.L. Michelucci ${ }^{2}$
}

${ }^{1}$ Istituto di Istologia ed Embriologia and ${ }^{2}$ Dipartimento di Matematica e Applicazioni, Facoltà di Scienze MM.FF.NN., Università di Palermo, Italy

Key words: Holothuria polii, periesophageal ring, inflammatory response, haemopoiesis

\section{SUMMARY}

In Holothuria polii, the periesophageal ring is an important organ supplying spherule cells after stimulation with foreign material. In animals injected with formalinized sheep erythrocytes, in fact, a depletion of spherule cells is observed in the periesophageal ring, whereas in the connective tissue, in the external epithelium and around the antigen-injected site, small, transparent cells can be visualized. It is supposed that the latter are stem cells of spherule cells.

\section{INTRODUCTION}

The invertebrates, as the vertebrates, have humoral and cellular mechanisms of defense. The presence of humoral substances such as aglutinins, lysins, lectins and other compounds that exert antigenic effects confers to invertebrates an immune capacity (Parrinello et al., 1976, 1979; Yeaton, 1981; Karp and Rheins, 1980; Reins et al., 1980; Ey and Jenkin, 1982; Amirante and Basso, 1984; Parrinello and Arizza, 1988, 1989; Olafsen, 1986; Canicattì, 1989, 1990, 1991; Parrinello, 1991; Vasta, 1991; Arizza et al., 1991, 1993; Cammarata et al., 1993; Lotzovà, 1993; Cooper et al., 1996; Vasquez et al., 1996; Arizza et al., 1997).

Besides the immune responses to introduced for- eign material or injected particulate material, are mediated principally by coelomocytes as observed in sipuncula (Dybas, 1981); molluses (Cheng and Galloway, 1970; Anderson, 1987), insect (Salt, 1970; Gotz and Vey, 1974; Nappi and Carton, 1986), tunicata (Anderson, 1971; Parrinello, 1981; Scofield and Nagashima, 1983; Parrinello et al., 1984; Parrinello and Patricolo, 1984; Raftos et al., 1987 a,b; Raftos and Cooper, 1991; De Leo, 1992).

Phagocytic activity was evidenced in sipuncula (Blanco et al., 1997) and tunicates (Smith, 1970; Anderson, 1971; Wright, 1974, 1981; Fuke, 1979; Rowley, 1981; Sawada et al., 1991; Ohtake et al., 1994; Ballarin et al., 1994; Parrinello and Cammarata, 1995).

Beck et al., (1993) isolated interleukin-1- like molecules which regulate cellular activities and enhance phagocytosis during inflammation by tunicate and echinoderm cells.

A cytotoxic activity was evidenced in sipuncula cells (Boiledien and Valembois, 1977), molluscs (Leippe and Renwantz, 1988; Franceschi et al., 1991), anellids (Porchet-Henneré et al., 1992; Suzuki and Cooper, 1995), crayfish (Tyson and Jenkin, 1974; Soderhall et al., 1985), tunicates (Fuke, 1980; Saito and Watanabe, 1982; Scofield and Nagashima, 1983; Raftos et al., 1987b, 1991; Sabbadin et al., 1992; Kelly et al., 1992; Parrinello and Arizza, 1992; Parrinello et al., 1993, 1995; Peddy and Smith, 1993, 1994; Nappi and Vass, 1993; Jackson

The authors dedicate this paper to the memory of Prof. Eleonora Patricolo,

Dipartimento di Biologia Animale, Università di Palermo.

Correspondence to: G. D’Ancona - E-mail: dancona@unipa.it 
et al., 1993; Arizza et al., 1995; Cammarata et al., 1995; Parrinello et al., 1996; Lipari et al., 1996), fishes (Cammarata et al., 2000).

In spite of extensive research on immunological reactivity, especially using tunicates, little is known about the echinoderms; and even less about the Holothuroidea (Hyman,1955; Smith, 1981; Cooper, 1982; Shinn, 1983; Dybas and Frankboner, 1986 ; Xing et al., 1998).

Recently genes expressed by activated coelomocytes were identified in echinoderms which encode proteins ( $\mathrm{SpC} 3$ and $\mathrm{SpBf}$ ) that are likely to be important in immune function (Smith et al.,1998; Al-Shariff et al., 1998; Gross et al.,1999; Gross et al., in press; Clow et al. in press.

These proteins constitute a simple complement cascade that act to opsonize foreign cells, particles and molecules for removal and destruction by the phagocytic coelomocytes. The identification of these proteins is important for understanding the evolution of the vertebrate immune system (Smith, 2000).

In the coelomic fluid of $H$. polii, three major categories of cells have been characterized and described both morphologically and functionally: amebocytes, spherule cells and progenitor cells (Canicattì et al., 1989; D’Ancona and Canicattì, 1990).

Amebocytes showed an intense phagocytic activity after antigenic stimulation (Canicattì and D'Ancona, 1989). These cells originate from the stone canal (D'Ancona, 1996) and combine to form nodules and brown bodies in the coelomic cavity (Canicattì et al, 1989) or in the Polian vesicle (D'Ancona et al., 1989). The aggregation of spherule cells and nodules gives rise to brown bodies. Type III spherule cells, in particular, are responsible for the production of melanin-like pigments, whereas type I cells produce an extracellular granular matrix which is found in both naturally and experimentally induced brown bodies (Canicattì and D'Ancona, 1989).

The periesophageal ring, in $H$. polii, is in turn, the structure carrying the water system and is connected with the coelomic cavity, the Polian vesicles and the stone canal. Since the Polian vesicles and the coelomic cavity are engaged in the inflammatory response after sheep erytrocyte injection, we have investigated the engagement of the periesophageal ring in the mechanism of defense.

Therefore, we have observed in this structure the numerical change of spherula cells during the different experimental conditions and the results were compared with those deriving from non injected animals (controls).

\section{MATERIALS AND METHODS}

Specimens of $H$. polii were collected from the Gulf of Palermo and maintained in tanks with running sea water at $15^{\circ}$. Pieces of digestive apparatus, including the periesophageal ring, were isolated from five animals, fixed in Bouin's solution, embedded in paraffin and sectioned with a microtome. The $7 \mu \mathrm{m}$ seriated sections were stained using the histochemical methods described by Mazzi (1977) and Ganter-Jollès (1970), herewith listed, and already used for the classification of spherule cells (D'Ancona and Canicattì, 1990):

- Gomori triple staining technique, i.e. a specific stain for collagen which evidences type II spherule cells.

- Sevki reaction to evidence type I spherule cells.

- Azocarmine-blue aniline-orange $G$ to evidence type III spherule cells.

\section{Preparation of $\mathbf{A S R B C}$}

Periesophageal rings were also collected from specimens subjected to antigenic stimulation. Sheep erythrocytes (SRBCs) were used as particulate antigens. After washing with phosphate-buffered saline, $\mathrm{pH} 7.4$ (PBS), a suspension of SRBCs was formalinized according to Csizmas's method (1960). The formalinized SRBCs (fSRBCs) were thoroughly washed in PBS and resuspended in the same buffer at a concentration of $6 \times 10^{8} \mathrm{cell} / \mathrm{ml}$. A single dose of $0.20 \mathrm{ml}$ of the above antigen suspension was injected into the coelomic cavity of four animals. These were then autopsied 20, 24, 48, 58 and $96 \mathrm{hrs}$ after the injection and their periesophageal rings subjected to the same procedures of non injected controls.

\section{RESULTS}

The periesophageal ring of $H$. polii is a canal made of connective tissue, and is large, being about $30 \mu \mathrm{m}$ in thickness (Fig. 1). By "proximal" is intended the extremity of the ring directed towards the mouth, "distal" being the opposite end. The cell distribution is summarized in Table I. In controls, spherule cells (type I, II and III) are found in both the proximal and the distal part of the periesophageal ring (Fig. 2), with no significant quantitative difference between the two parts. Type I and II cells are ubiquitous and more numerous than type III, which are 

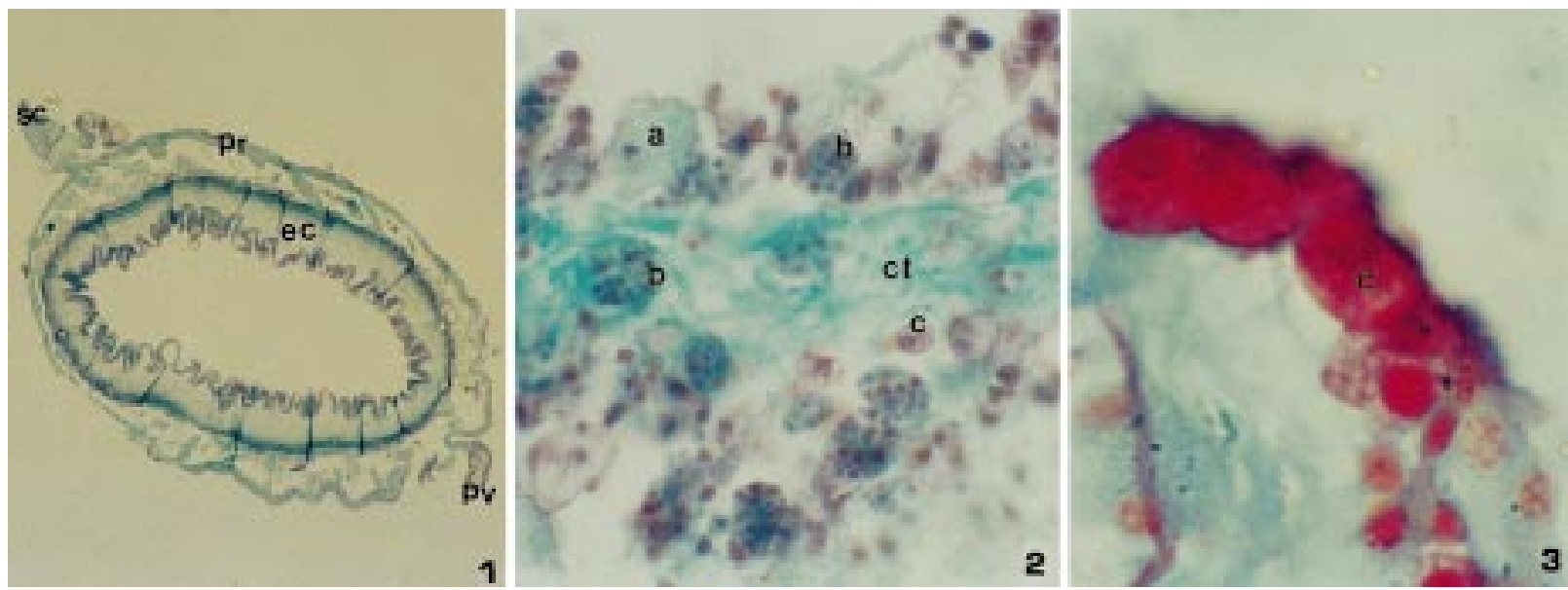

Figs. 1/3 - (1)Non injected specimens. Cross section of the esophageal canal (ec) with the periesophageal ring (pr). The figure shows also the stone canal (sc) and the Polian vesicle (pv). Magnification 18,8x. (2)Selected image of the periesophageal ring. The figure shows type I spherule cells (a), type II (b), type III (c) in the connective tissue (ct). Magnification 504x. (3)Selected image of type III spherule cells (c), some of which are degranulated. Magnification 1100x.

prevalently present in the proximal part (Table II). Morphologically, type I and II spherule cells appear to be more transparent, small and disorganized than type III. Sometimes type II cells are reduced in number, with a small or defective inner protein core. Some type III spherule cells lack granules and show little affinity to the dye (Fig. 3). In the periesophageal ring, brown masses and brown bodies of variable size are also found; the same has already been observed in the coelomic cavity (Canicattì and D'Ancona, 1989) and in the Polian vesicle (D'Ancona et al., 1989) of $H$. polii.

On account of the lack of significant differences found in controls between the average amounts of spherule cells in the proximal and in the distal part of the periesophageal ring, for the injected specimens only the times of antigenic stimulation are considered. The results are summarized in Table III and in Graph 1. It is evident that type I and II spherule cells are reduced numerically over 48 hrs of stim- ulation. At the same time, the connective tissue becomes looser and small spherical cells (2-5 $\mu \mathrm{m})$, some of which are active in mitosis, others in migration (Figs. 4, 8 ) are found among collagen fibres, particularly on their internal side. Immediately afterward, type I and II spherule cells duplicate and then remain unchanged until $96 \mathrm{hrs}$ of stimulation. Also type III cells are reduced numerically and disappear $48 \mathrm{hrs}$ after injection (Fig. 5). They reappear 58 and $96 \mathrm{hrs}$ after injection but their amount is significantly lower than that found in controls (Figs. 1, 6, 7). After 20 hrs of stimulation, formalinized erythrocytes (antigens) surrounded by amoebocytes, by a few mature type I spherule cells and by numerous small spherical cells with metachromatic granules, can be observed in the space between the wall of the alimentary canal and the periesophageal ring (Fig. 9). Four hrs later, type I spherule cells produce a large amount of extracellular granular matrix (Fig. 10).

Table I

Mean and standard error of the proximal and distal part cells of the periesophageal ring of 5 non injected animals (controls)

\begin{tabular}{lccc}
\hline Spherule cells & Number of spherule cells & \\
\hline & Proximal part (pp) & Distal part (dp) & P \\
\hline Type I & $227.28 \pm 17.6$ & $260.50 \pm 23.3$ & $>0.5$ \\
Type II & $169.14 \pm 24.5$ & $223.43 \pm 39.4$ & $>0.4$ \\
Type III & $74.00 \pm 10.3$ & $69.43 \pm 30$ & $>0.9$ \\
\hline
\end{tabular}


Table II

Student' s ( $\mathrm{t}$ ) test between cell pairs in pp and $\mathbf{d p}$ of animals in Table I

\begin{tabular}{llllc}
\hline Spherule cells & $\mathrm{t}(\mathbf{p p})$ & $\mathrm{P}$ & $\mathrm{t}(\mathbf{d p})$ & $\mathrm{P}$ \\
\hline Type I - Type II & 1.351 & $>0.2$ & 0.509 & $>0.6$ \\
Type II- Type III & 2.457 & $>0.05$ & 2.268 & $>0.05$ \\
Type I - Type III & 5.546 & $<0.05$ & 3.823 & $<0.05$ \\
\hline
\end{tabular}

\section{DISCUSSION}

In controls, the difference between the average amount of spherule cell types found in the proximal and in the distal part of the periesophageal ring is not significant. Consequently, the distribution of spherule cells can be considered to be random. On the contrary, the comparison of each cell type against the two other types shows that between type I and II the difference is not significant, whereas between type II and III the difference is noticeable, and remarkable between type I and III. Therefore, in the proximal part of the periesophageal ring, both type I and II are equally distributed and more numerous than type III cells. In the same area of the injected animals, spherule cells are reduced in number. The above results are consistent with the processes occurring during the cellular immune response induced in $H$. polii. The cellular events taking place after injection of sheep erythrocytes into the coelomic cavity, are in fact various (Canicattì and D'Ancona, 1989) and include, throughout the $96 \mathrm{hrs}$ of injection, the recruitment of a large number of amoebocytes from the stone canal (D’Ancona, 1996), in order to eliminate the injurious agents by phagocytosis. The amoebocytes cluster in a syncytial structure which tends to form nodular aggregates and brown bodies.

The nodules are surrounded by type I and II spherule cells which produce an extracellular granular matrix, constituted of acid and neutral mucopolysaccarides and hydrolytic enzymes, having a cementing action (D'Ancona and Canicattì, 1990). Brown bodies are also surrounded by type III spherule cells, whose positive Schmorl's reaction suggests the presence of melanin (Canicattì and D'Ancona 1989).

$H$. polii is a benthic animal (Tortonese, 1965) subjected to a long list of commensals and parasites (Jangoux, 1987 a, b, c). Therefore, the discovery of brown masses and brown bodies in the periesophageal ring of the injected specimens proves the necessity of the animal to react readily to the attack of likely natural antigens, taking place through the mouth. Moreover, the morphological alterations and reduced affinity to the dye found, in controls, in the spherule cells of the periesophageal ring, support the hypothesis of their contribution to the local making of brown bodies. As a consequence, the periesophageal ring acts as a supplier of spherule cells and is engaged in the immune reaction. However, what is the origin of the new spherule cells which, $58 \mathrm{hrs}$ after injection, begin to repopulate the periesophageal ring? Ohuye (1938) proposed that in various invertebrates, including two holothurian species, lymphocytes represent primitive pluripotent cells from which all the other coelomocyte types are derived. Endean (1958) indicated that in $H$. leucospilata, amoebocytes originate from the

Table III

Mean and standard error of spherule cells after different times of antigen stimulation. Four specimens were used for each stimulus time

\begin{tabular}{|c|c|c|c|}
\hline \multirow{2}{*}{$\begin{array}{l}\text { Hours of } \\
\text { antigenic } \\
\text { stimulation }\end{array}$} & \multicolumn{3}{|c|}{ Number of spherule cells } \\
\hline & Type I & Type II & Type III \\
\hline 20 & $49.0 \pm 3.4$ & $104.0 \pm 8.6$ & $3.75 \pm 0.50$ \\
\hline 24 & $71.0 \pm 10.7$ & $125.0 \pm 10.8$ & $5.75 \pm 2.05$ \\
\hline 48 & $59.0 \pm 5.6$ & $69.0 \pm 4.3$ & 0 \\
\hline 58 & $96.2 \pm 8.2$ & $136.7 \pm 17.0$ & 2.4 \\
\hline 96 & $80.5 \pm 2.3$ & $168.7 \pm 23.7$ & $17.2 \pm 5.50$ \\
\hline
\end{tabular}




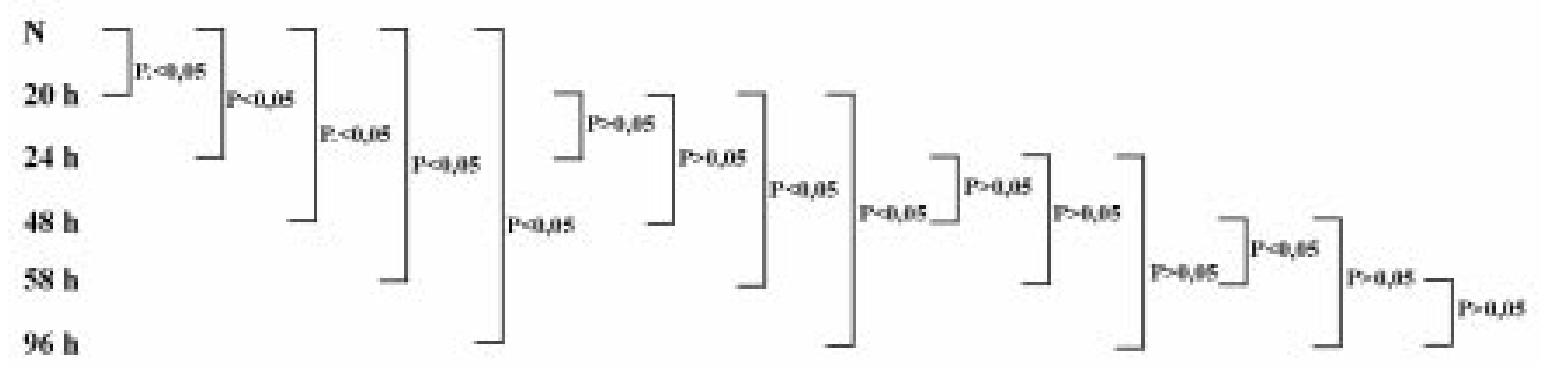

\section{b}

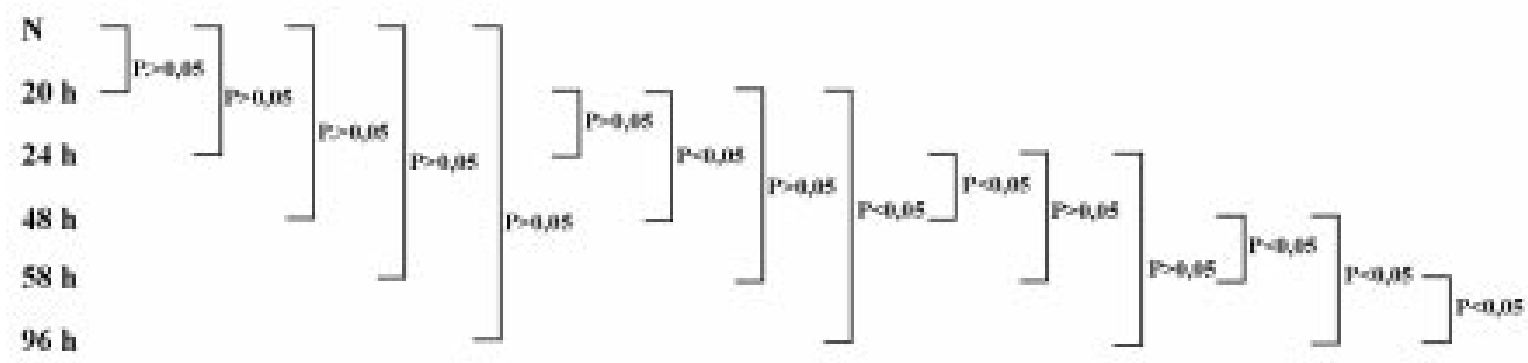

c

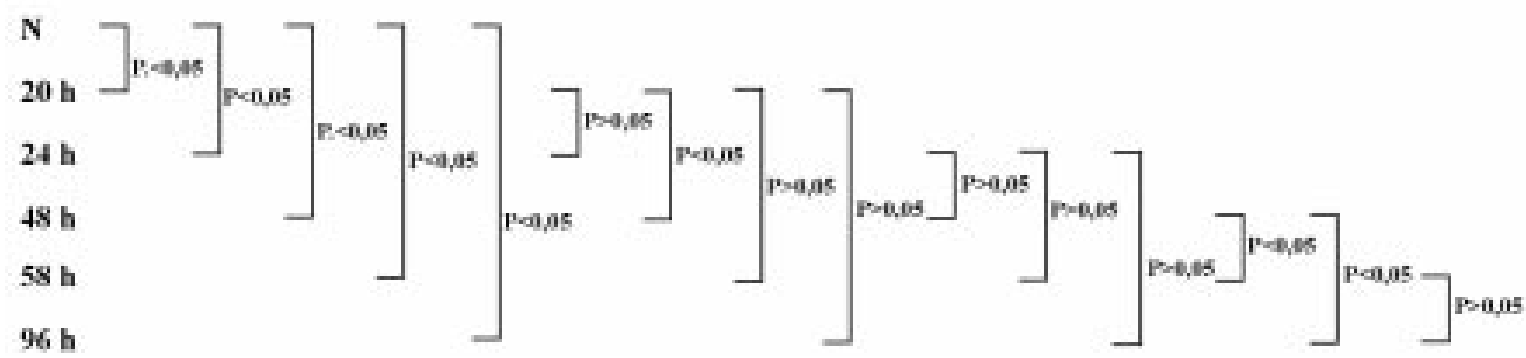

Graph 1 - Probability that numerical differences between controls and stimulated cells are random as calculated by Student's (t). a= type I spherule cells; $b=$ type II; $c=$ type III. $\mathrm{N}=$ uninjected animals (controls).

lining epithelium of respiratory trees, migrate into the coelomic fluid and then differentiate into spherule cells. Observations by Hetzel (1965) indicate that at least some of the lymphocytes may differentiate from mesenchymal connective tissue cells located in the walls of the hemal vessels, and that lymphocyte-like cells of the hemal vessels possibly differentiate into spherule cells.

We suppose that the small spherical cells observed in the connective tissue $20 \mathrm{hrs}$ after injection are stem cells of spherule cells. This hypothesis is confirmed by their mitotic activity and by the concurrent presence of metachromatic, not yet mature, granules, and mature spherule cells, both in the periesophageal ring and around the antigen. The majority of small spherical cells are found in organs showing inflammatory responsiveness, such as the Polian vesicle and the coelomic cavity (D'Ancona et al., 1989; Canicattì and D'Ancona, 1989). Since mitotic figures were not observed in any of the circulating spherule cells and amoebocytes, it is likely that the periesophaeal ring acts also as a hemopoietic organ of spherule cells. The latter, at times of heavy antigenic stress, are prematurely released but are able to ripe out of the centre of origin. 

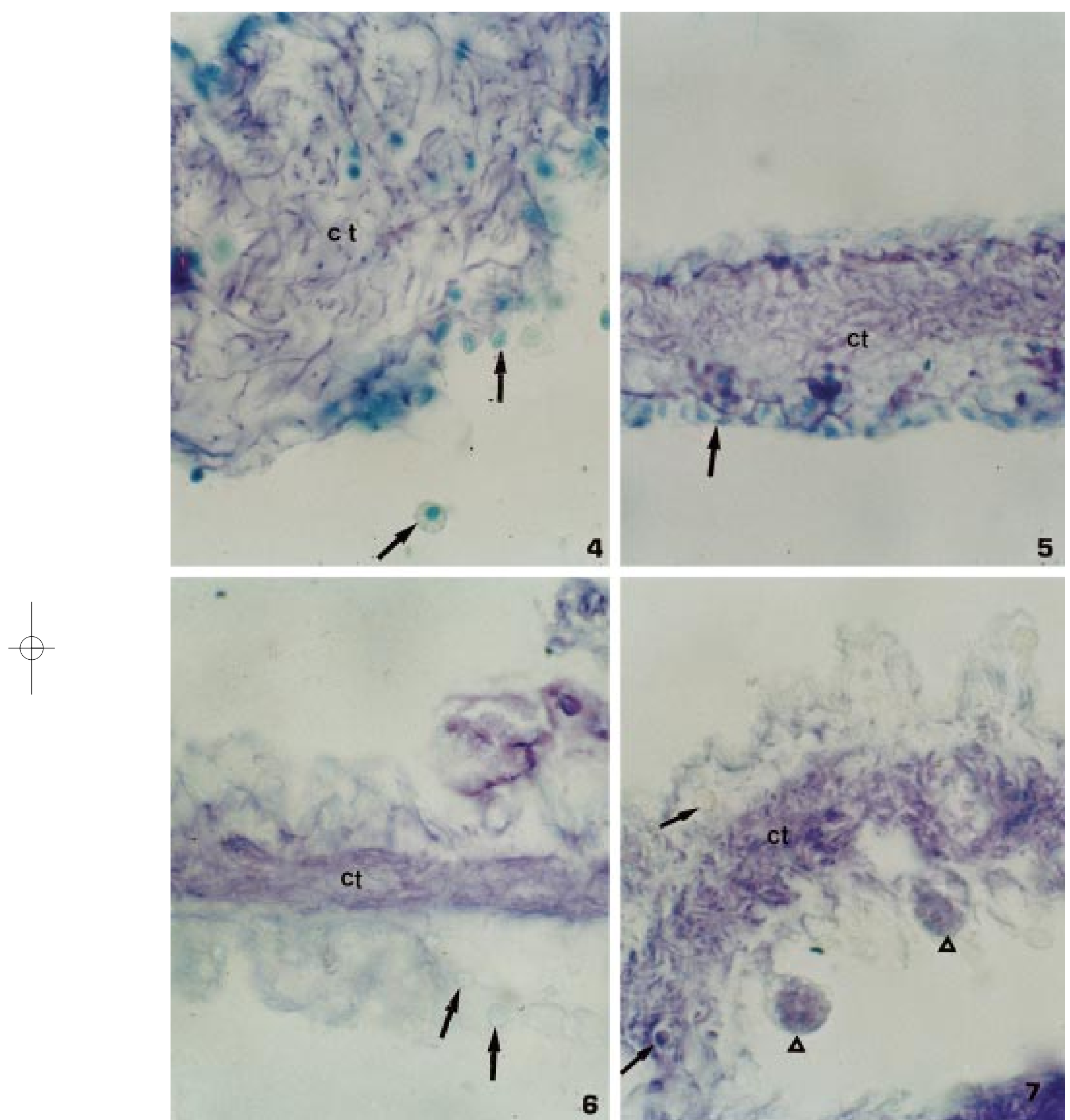

Figs. 4-7 - Injected specimens. Cross sections of the perioesophageal ring coloured with toluidine blue. Magnification 800x. Twenty hrs after fSRBC injection (4), the connective tissue (ct) is very loose and devoid of mature cells; it shows small colourless spherule cells in migration $(\rightarrow)$. Forty-eight (5) and fifty-eight (6) hrs after injection, the connective tissue is less and less loose and presents small cells on the margins $(\rightarrow)$. Ninety-six $(7)$ hrs after injection the structure of the connective tissue is compact with not yet mature $(\rightarrow)$ cells and some mature $(\Delta)$ ones. 

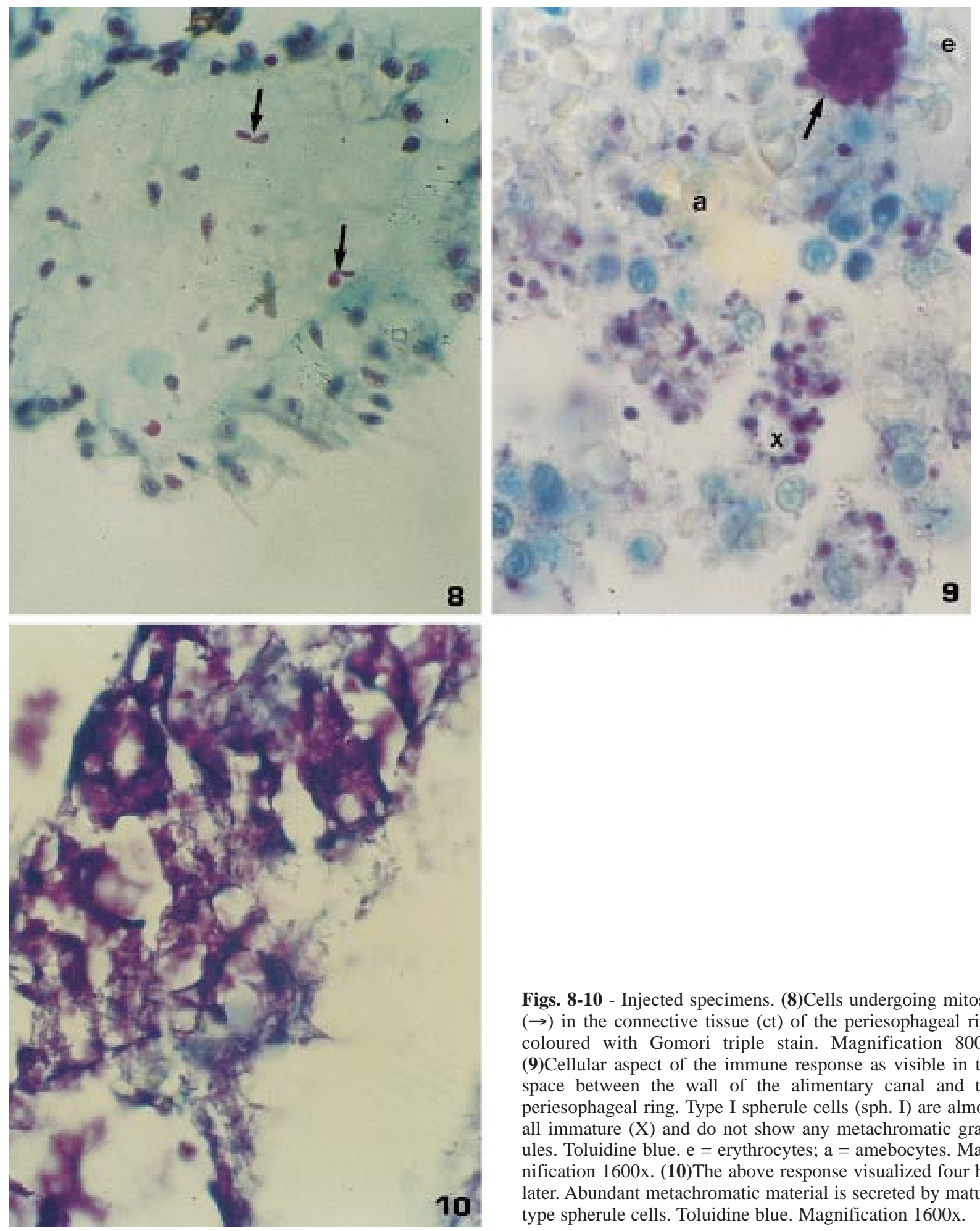

Figs. 8-10 - Injected specimens. (8)Cells undergoing mitosis $(\rightarrow)$ in the connective tissue (ct) of the periesophageal ring coloured with Gomori triple stain. Magnification 800x. (9)Cellular aspect of the immune response as visible in the space between the wall of the alimentary canal and the periesophageal ring. Type I spherule cells (sph. I) are almost all immature $(\mathrm{X})$ and do not show any metachromatic granules. Toluidine blue. $\mathrm{e}=$ erythrocytes; $\mathrm{a}=$ amebocytes. Magnification 1600x. (10)The above response visualized four hrs later. Abundant metachromatic material is secreted by mature type spherule cells. Toluidine blue. Magnification 1600x. 


\section{REFERENCES}

Al-Sharif W.Z., Sunyer J.O., Lambris J.D., and Smith L.C.: A homologue of the complement component $\mathrm{C} 3$ is specifically expressed in sea urchin coelomocytes. J. Immunol. 160, 29832997, 1998.

Amirante G.A., and Basso V.: Synthesis of lectins in Squilla mantis L. (Crustacea Stomatopoda) using monoclonal antibodies. Dev. Comp. Immunol. 8, 721-726, 1984.

Anderson R.S.: Cellular responses to foreign bodies in the tunicate Molgula manhattensis (DeKay). Biol. Bull. 141, 9198, 1971.

Anderson R.S.: Polycaryon formation by Mercenaria mercenaria hemocytes. Biol. Bull., 172, 236-245, 1987.

Arizza V., Parrinello N., and Schimmenti S.: In vitro release of lectins from hemocytes of Phallusia mamillata. Dev. Comp. Immunol. 15, 219-226, 1991.

Arizza V., Parrinello N., and Cammarata M.: Immunocytochemical localization of cellular lectins in Phallusia mamillata hemocytes. Anim. Biol. 2, 15-22, 1993.

Arizza V., Cammarata M., Tomasino M.C. and Parrinello N.: Phenoloxidase characterization in vacuolar hemocytes from the solitary ascidian Styela plicata. J. Invertebr. Pathol. 66 , 297-302, 1995.

Arizza V.,Cooper E.L., and Parrinello N.: Circulating hemocytes and pharyngeal explants of Styela clava release hemagglutinin in vitro. J. Mar. Biotechnol. 1997.

Ballarin L., Cima F., and Sabbadin A.: Phagocytosis in the colonial ascidian Botrillus sclosseri. Dev. Comp. Immunol. 18, 467-481, 1994.

Ballarin L.F., Cima F., and Sabbadin A.: Morula cells and histocompatibility in the colonial ascidian Botryllus Schlosseri. Zool. Sci. 12, 757-764, 1995.

Beck G., O’Brien R., Habicht G.S., Stilman D.L., Cooper E.L., and Raftos D.A.: Invertebrate cytokines III: Invertebrate interleukin-1-like molecules stimulate phagocytosis by tunicate and echinoderm cells. Cell. Immunol. 146, 284-299, 1993.

Blanco G.A., Escalada A.M., Alvarez E., and Hajos S.: LPSinduced stimulation of phagocytosis in the sipunculan worm Themiste petricola: possible involvement of human CD14, CD11B and CD11C cross-reactive molecules. Dev. Comp. Immunol. 21, 349-362, 1997.

Boiledien D., and Vallembois P.: Natural cytotoxic activity of sipunculid leukocytes on allogenic and xenogenic erythrocytes. Devel. Comp. Immunol. 1 (3), 207-216, 1977.

Cammarata M., Parrinello N., and Arizza V.: In vitro release of lectins from Phallusia mamillata hemocytes after their fractionation on a density gradient. J. Exp. Zool. 266, 319-327, 1993.

Cammarata M., Candore G., Arizza V., Caruso C., and Parrinello N.: Cytotoxic activity of Styela plicata hemocytes against mammalian cell targets: II. Properties of the in vitro reaction against human tumour cell lines. Anim. Biol. 4, 139-144, 1995.

Cammarata M., Vazzana M., Cervello M., Arizza V., and Parrinello N.: Spontaneous cytotoxic activity of eosinophilic granule cells separated from the normal peritoneal cavity of Dicentrarchus labrax. Fish \& Shellfish Immunology 10, 143154, 2000.
Canicattì C.: Evolution of lytic system in echinoderms. II Naturally occurring hemolytic activity in Marthasterias glacialis (Asteroidea). Comp. Biochem. Phisiol. 93A, 587$591,1989$.

Canicattì C.: Hemolysins: pore-forming proteins in invertebrates. Experientia 46, 239-244, 1990.

Canicattì C.: Binding properties of Paracentrotus lividus (Echinoidea) hemolysin. Comp. Biochem. Physiol. 98A, 463$468,1991$.

Canicattì C., and D'Ancona G.: Cellular aspects of Holothuria polii immune response. Biol. Bull, 53, 152-158, 1989

Canicattì C., D'Ancona G., and Farina-Lipari E.: The coelomocytes of Holothuria polii (Echinodermata). I. Light and electron microscopy. Boll. Zool. 56, 29-36, 1989.

Canicattì C., D'Ancona G., and Farina-Lipari E.: The Holothuria polii brown bodies. Boll. Zool, 56, 275-283, 1989.

Cheng T.C., and Galloway P.C.: Transplantation immunity in molluscs: The histoincompatibility of Helisoma duriy normale with allographs and xerographs. J. Invertebr. Pathol. 15, 177-192, 1970 .

Clow L. A., Gross P.S. Shih C.S., and Smith L.C.: Expression of $\mathrm{SpC} 3$, the sea urchin complement component, in response to lipopolysaccharide. Immunogenetics, 12, 1021-1033, 2000.

Cooper E.L.: In: The reticuloendothelial system, Vol. 3, "Phylogeny and Ontogeny" (Cohen M. and Sigel M.M. Eds.) 1-35. Plenum, New York. 1982.

Cooper E.L., Mansour M.H., and Negm H.I.: Marine invertebrate immunodefense response: molecular and cellular approaches in tunicates. Ann. rev. Fish Dis. 6, 133-149, 1996.

Csizimas L.: Preparation of formalinized erythrocytes. Pro. Soc. Biol. N.Y. 103, 157, 1960.

D'Ancona G.: A haemopoietic organ in Holothuria polii (Holothuroidea), Anim. Biol. 5, 47-53, 1996.

D’Ancona G., Rizzuto L., and Canicattì C.: Engagement of Polian vesicles during Holothuria polii response to erythrocyte injection. J. Invertebr. Pathol. 54, 300-305, 1989.

D'Ancona G., and Canicattì C.: The coelomocytes of Holothuria polii (Echinodermata). II. Cytochemical staining properties. Bas. Appl. Histochem. 34, 209-218, 1990.

De Leo G.: Ascidian hemocytes and their involvement in defence reactions. Boll. Zool. 59, 195-214, 1992.

Dybas L.: Cellular defense reactions of Phascolosoma agassizii, a sipunculan worm. Phagocytosis by granulocytes. Biol. Bull. 161, 104-114, 1981.

Dybas L., and Fankboner P.V.: Holothurian survival strategies: Mechanism for the manintenance of a bacteriostatic environment in the coelomic cavity of the sea cucumber Parasticopus californicus. Dev. Comp. Immunol. 10, 311-330, 1986.

Endean R.: The coelomocytes of Holothuria leucospilota. Quart. J. Microsc. Sci., 99, 47-60, 1958.

Ey P.L., and Jenkin C.R.: Molecular basis of self-non self discrimination in the invertebrata. In : Cohen N. and Sigel M.M. (eds), The Reticuloendothelial System. Plenum Press, New York and London,Vol. 3, 360-365, 1982. 
Franceschi C, Cossarizza A., Monti D., and Ottaviani E.: Cytotoxicity and immunocyte markers in cells from the freshwater snail Planorbarius corneus L.(Gastropoda pulmonata): implication for the evolution of natural killer cells. Eur. J. Immunol. 21, 489-493,1991.

Fuke M.T.: Studies on coelomic cells of some Japanese ascidians. Bull. Mar. Biol. Stn. Asamushi Tohoku Univ. 16, 142159, 1979.

Fuke M.T.: Contact reaction between xenogeneic or allogeneic coelomic cells of solitary ascidians. Biol. Bull. 158, 304$315,1980$.

Ganter P., and Jollès G.: Histochimie normale et pathologique. Vol. 2, Gauthier-Villars, Paris, 1970.

Gotz P., and Vey A.: Humoral encapsulation in Diptera (Insecta): defense reactions of Chirinomus larvae against fungi. Parasitology 68, 193-205, 1974.

Gross P.S., Al-Sharif W.Z., Cow L.A., and Smith L.C.: Echinoderm immunity and the evolution of the complement system. Dev. comp. Immunol. 23, 429-442, 1999.

Gross P.S., Clow L.A., and Smith L.C.: SpC3, the complement homologue from the purple sea urchin, Strongylocentrotus purpuratus, is expressed in two subpopulations of the phagocytic coelomocytes. Immunogenetics, 12, 1034-1044, 2000.

Hetzel H.R.: Studies on holothurian coelomocytes. II. The origin of coelomocytes and the formation of brown bodies. Biol. Bull. 128, 102-111, 1965.

Hyman L.H.: The invertebrates vol. IV Echinodermata. Mc Graw-Hill Book Co., New-York, 1995.

Jackson A.D., Smith V.J., and Peddie C.M.: In vitro phenoloxidase activity in the blood of Ciona intestinalis and other ascidians. Dev. Comp. Immunol. 17, 97-108, 1993.

Karp R.D., and Coffaro K.A.: Cellular defence system of the Echinodermata. In: Cohen N. and Sigel M.M.(eds). The Reticuloendothelial System. Plenum Press, New York and London 3, 257-282, 1982.

Karp R.D., and Rheins L.A.: Induction of specific humoral immunity to soluble proteins in the American cockroach (Periplaneta americana). II. Nature of the secondary response. Dev. Comp. Immunol. 4, 629-639, 1980.

Kelly K.L., Cooper E.L., and Raftos D.A.: In vitro allogeneic cytotoxicity in the solitary urochordate Styela clava. J. Exp. Zool. 262, 202-208, 1992.

Leippe M., and Renwrantz L.: Release of cytotoxic and agglutinating molecules by Mytilus hemocytes. Dev. Comp. Immunol. 12, 297-308, 1988.

Lipari L., Cammarata M., Arizza V., and Parrinello D.: Cytotoxic activity of Styela plicata hemocyte against mammalian cell targets: I. Properties of the in vitro reaction againts erythrocytes. Anim. Biol. 4, 131-137, 1995.

Lotzovà E.: Immune surveillance and natural immunity. In: Cooper E.L., Nisbet-Brown, E., eds., Developmental Immunology. New York. Oxford University Press, 1993.

Luquet G. and Le Clerc M.: Spontaneous and induced cytotoxicity of axial organ cells from Asterias rubens (Asteridechinoderm). Immunol. Lett. 6, 339-342, 1983.
Mazzi V.: Manuale di Tecniche Istologiche e Istochimiche. Piccin Ed., Padova, pp. 399-609, 1977.

Nappi A.J. and Carton Y.: Cellular immune responses of Drosophila. In Bréhelin, M. (ed) Immunity in Invertebrates, Springer-Verlag. Berlin. 13, 171-187, 1986.

Nappi A.J. and Vass E.: Melanogenesis and the generation of cytotoxic molecules during insect cellular immune reactions. Pigment Cell Res. 6, 117-126, 1993.

Ohtake S.I., Abe T., Shishikura F., and Tanaka K.: The phagocytes in hemolymph of Halocynthia roretzi and their phagocytic activity. Zool. Sci. 11, 681-691, 1994.

Ohue T.: On the coelomic corpuscle in the body fluid of some invertebrates XII. General considerations on the results obtained by preceding investigations. Sci. Repts. Tohoku Univ., ser. 4, Biol. 13, 359-379, 1938.

Olafsen J.A.: Invertebrate lectins: Biochemical heterogeneity as a possible key to their function. In: Immunity in Invertebrates. (M. Brehelin, editor) Springer-Verlag. Berlin, 94-111, 1986.

Ohtake S.I., Abe T., Shishikura F., and Tanaka K.: The phagocytes in hemolymph of Halocynthia roretzi and their phagocytic activity. Zool. Sci. 11, 681-691, 1994.

Parrinello N.: The reaction of Ciona intestinalis L. (Tunicata) to subcuticular erythrocyte and protein injection. Dev. Comp. Immunol. 5 (Supp.) 1, 105-110, 1981.

Parrinello N.: Animal lectins and immune recognition: a phylogenetic approach. In: Form and Function in Zoology (G. Lanzavecchia and R. Valvassori, editors). Selected Symposia and Monographs, 5. Mucchi Editore, Modena, 43-68, 1991.

Parrinello N.: Cytotoxic activity of tunicate hemocytes. In: Progress in Molecular and Subcellular Biology. Invertebrate Immunology, Vol. 15 (B. Rinkevich and W.E.G. Muller, editors), Springer-Verlag, Berlin, 190-217, 1995.

Parrinello N., and Cammarata M.: Collection, separation, identification and phagocytic activity of tunicate hemocytes. Techn. Fish Immunol. 4, 1-16, 1995.

Parrinello N., Canicattì C., and Rindone D.: Naturally occurring hemagglutinins in the coelomic fluid of the Echinoderms Holothuria polii Delle Chiaje and Holothuria tubolosa Gmelin. Boll. Zool. 43, 259-271,1976.

Parrinello N., Rindone D., and Canicattì C.: Naturally occurring hemolysins in the coelomic fluid of Holothuria polii Delle Chiaje (Echinodermata). Dev. Comp. Immunol. 3, 45-54, 1979.

Parrinello N., Patricolo E., and Canicattì C.: Inflammatorylike reactions in the tunic of Ciona intestinalis (Tunicata). I Encapsulation and tissue injury. Biol. Bull. 167, 229-273, 1984.

Parrinello N., and Patricolo E.: Inflammatory-like reaction in the tunic of Ciona intestinalis (Tunicata). II. Capsule components. Biol. Bull. 167, 238-250, 1984.

Parrinello N., and Arizza V.: Sugar- specific lectins from the tunicate Ascidia malaca: Subunit characterization and hemocyte surface distribution. Dev. Comp. Immunol. 12, 495-507, 1988.

Parrinello N., and Arizza V.: Sugar-specific cellular lectins of Phallusia mamillata hemocytes: Purification, characteriza- 
tion and evidence for cell-surface localization. Dev. Comp. Immunol. 13, 113-121, 1989.

Parrinello N., and Arizza V.: Cytotoxic activity of invertebrate hemocytes with preliminary findings on the tunicate Ciona intestinalis. Boll. Zool. 59, 183-190, 1992.

Parrinello N., Cammarata M., Arizza V., and Lipari L.: Sphingomyelin-inhibitable natural cytotoxic activity of Ciona intestinalis granulocyte towards erythrocyte targets. Proceedings of the $54^{\text {th }}$ Congress of Unione Zoologica Italiana. Centro stampa Università degli Studi, Perugia, 1992.

Parrinello N., Arizza V., Cammarata M., and Parrinello D.M.: Cytotoxic activity of Ciona intestinalis (Tunicata) hemocytes: properties of the in vitro reaction against erythrocyte targets. Dev. Comp. Immunol. 17, 19-27, 1993.

Parrinello N., Cammarata M., Lipari L., and Arizza V.: Sphingomyelin inhibition of Ciona intestinalis (Tunicata) cytotoxic hemocytes assayed against sheep erythrocytes. Dev. Comp. Immunol. 19, 31-41, 1995.

Parrinello N., Cammarata M., and Arizza V.: Univacuolar refractile hemocytes from the tunicate Ciona intestinalis are cytotoxic for mammalian erythrocytes in vitro. Biol. Bull. 190, 418-425, 1996.

Peddy C. M., and Smith V.: In vitro cytotoxic activity against mammalian target cells by the hemocytes of the solitary ascidian, Ciona intestinalis. J. Exp. Zool. 267, 616-623, 1993.

Peddy C. M., and Smith V. J.: Mechanism of cytotoxic activity by hemocytes of the solitary ascidian, Ciona intestinalis. J. Exp. Zool. 270, 335-342, 1994.

Porchet-Henneré E., Dugimont T., and Fischer A. Natural killer cells in a lower invertebrate, Nereis diversicolor. Eur. J. Immunol. 58, 99-107, 1992.

Raftos D.A., Tait N.N., and Briscoe D.A.: Allograft rejection and alloimmune memory in the solitary urochordate, Styela plicata. Dev. Comp. Immunol. 11, 343-351, 1987a.

Raftos D.A., Tait N.N., and Briscoe D.A.: Cellular basis of allograft rejection in the solitary urochordate,Styela plicata. Dev. Comp. Immunol. 11, 713-725, 1987b.

Raftos D.A., and Cooper E.L.: Proliferation of lymphocytelike cells from the solitary tunicate, Styela clava, in response to allogenic stimuli. J. Exp. Zool. 260, 391-400, 1991.

Raftos D.A. and Huchinson A.: Cytotoxicity reactions in the solitary tunicate Styela plicata. Develop. and Comp. Immunol. 19, 463-472, 1995.

Rheins L.A., Karp R.D., and Butz A.: Induction of specific humoral immunity to soluble proteins in the American cockroach (Periplaneta americana). I. Nature of the primary response. Dev. Comp. Immunol. 4, 447-458, 1980.

Rowley A.F.: The blood cells of the sea squirt, Ciona intestinalis: Morphology, differential counts, and in vitro phagocytic activity. J. Invertebr. Pathol. 37, 91-100, 1981.

Sabbadin A., Zaniolo G., and Ballarin L.: Genetic and cytological aspects of histocompatibility in . ascidians. Boll. Zool. 59, 167-173, 1992.

Salt G.: The cellular defence reactions of insects. Cambridge University Press, London, 1970.

Sawada T., Fujikura Y.,Tomonaga S., and Fukumoto T.: Clas- sification and characterization of ten types of hemocytes in tunicate Halocynthia roretzi. Zool. Sci. 8, 939-950, 1991.

Shinn G.L.: Reproduction of Anoplodium bymanae, a turbellarian flatworm (Neorhabdocoela, Umagillidae) inhabiting the coelom of sea cucumber; production of egg capsules, and escape of infective stages without evisceration of the host. Biol. Bull., 169, 182-198, 1985.

Scofield V.L., and Nagashima L.S.: Morphology and genetics of rejections between oozoids from the tunicate Botrillus schlosseri. Biol. Bull. 165, 733-744, 1983.

Smith M.J.: The blood cells and tunic of the ascidian Halocynthia aurantum (Pallas). II. Histochemistry of the blood cells and tunic. Biol. Bull. 138, 379-388, 1970.

Smith U.Z.: The Echinoderms. In: Ratchliffe N.A. and Rowley A.F. (eds), Invertebrate Blood Cells Academic Press, London, 2, 513-562, 1981.

Smith V.J., and Peddie C.M.: Cell cooperation during host defense in the solitary tunicate Ciona intestinalis (L) Biol. Bull. 183, 211-219, 1992.

Smith L.C., Shih C.S., and Dachenhausen S.G.: Coelomocytes specifically express $\mathrm{SpBf}$, a homologue of factor B, the second component in the sea urchin complement system. Journal of Immunology 161, 6784-6793, 1998.

Soderhall K., Wingren A., Joahansson M.V., and Bertheussen K.: The cytotoxic reaction of hemocytes from the freshwater crayfish Astacus astacus. Cell. Immunol. 94, 326-332, 1985.

Suzuki M.M. and Cooper E.L.: Killing of intrafamiliar leukocytes by the earthworm effector cells. Immunol. Lett. 44, 4549,1995

Tyson C. J., and Jenkin, C.R.: The cytotoxic effect of haemocytes from the crayfish (Pracentrotus bicarinatus) on tumor cells of vertebrates. Aust. J. Exp. Biol. Med. Sci. 52, 915-923, 1974.

Tortonese E.: Echinodermata. Ed. Calderini, Bologna, 1985.

Vasquez L., Jaramillo L., Lascurain R., Cooper E..L., Rosas P., and Zenteno E.: Bacterial agglutination by the sialic acid specific serum lectin from Macrobrachium rosembergii. Comp. Biochem. Physiol. 113B, 355-359, 1996.

Vasta G.R.: The multiple biological roles of invertebrate lectins: Their participation in non self recognition mechanisms. In: Phylogenesis of Immune Function (G.W. Warr and N. Cohen, editors). CRC Press, Boca Raton, FL, 73-101, 1991.

Wright R.K.: Protochordate immunity I. Primary immune response of the tunicate Ciona intestinalis to vertebrate erythrocytes. J. Invert. Pathol. 24, 29-36, 1974.

Wright R.K.: Urochordates. In: Invertebrate Blood Cells, Vol. 2 (Ratcliffe N.A. and Rowley A. F., editors). Academic Press. London 565-626, 1981.

Xing J., Leung M.F., and Chia F.S.: Quantitative analysis of phagocytosis by amebocyta of a sea cucumber Holothuria leucospilota. Invertebrate Biology, 117 (1), 67-74, 1998.

Yeaton R.: Invertebrate lectins XI. Diversity of specificity, biological synthesis and function in recognition. Dev. Comp. Immunol. 5, 535-545, 1981 